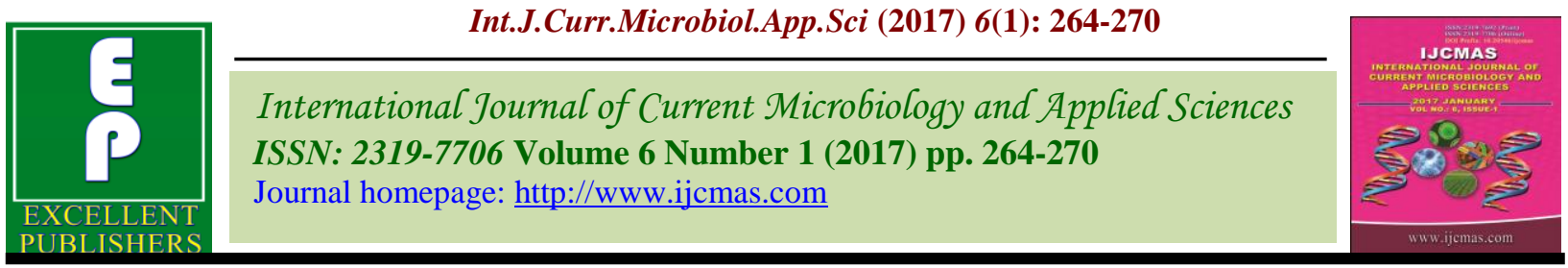

Original Research Article

http://dx.doi.org/10.20546/ijcmas.2017.601.032

\title{
Screening of Competitor Mould in Oyster Mushroom (Pleurotus florida) Cultivation and their Management
}

\author{
R. Senthil Kumar* and V. Sarathi \\ ${ }^{1}$ Department of Microbiology, PG Extension Center, Bharathidasan University, \\ Perambalur, Tamilnadu, India \\ ${ }^{2} \mathrm{PG}$ and Research Department of Microbiology, J.J College of Arts and Science, \\ Pudukkottai, Tamilnadu , India \\ *Corresponding author
}

A B S T R A C T

\begin{tabular}{|l|}
\hline K e y w o r d s \\
Oyster mushroom, \\
competitor moulds, \\
cultivation, \\
sterilization.
\end{tabular}

\section{Introduction}

Oyster mushroom (Pleurotus sp.) belonging to class Basidiomycetes and family Agaricaceae is popularly known as 'dhingri' in India. The popularity of oyster mushroom has been increasing due to its ease of cultivation, high yield potential and high nutritional value (Banik et al., 2004; Gregori et al., 2007). Mushrooms are now-a-days popularly known as functional foods (Liu et al., 2003). Bioconversion of lignocelluloses residues through cultivation of Pleurotus offers the best prospect to utilize renewable resources in the production of protein rich food that will sustain food security for peoples (Naraian et al., 2009). Oyster mushroom help to remove the toxicity produces by the agro wastes (Fan et al., 2000a, b). During oyster mushroom cultivation, mushroom growers facing various problems especially competitor moulds damage the mushroom beds and reduce yield. Studies on various aspects of fungal contaminants and diseases of Pleurotus spp. were undertaken by various workers (Castle et al., 1998; Mamoun et al., 2000) and they reported Trichoderma harzianum, Aspergillus 
sp., Penicillium sp., Monilia sitophila, Stemonitis sp. and Coprinus sp. were the major contaminants of Pleurotus sp. These species become prevalent in Pleurotus cultures if the substrate has not been uniformly or properly pasteurized. Among these contaminants, $T$. harzianum was reported to be the most damaging one, competing aggressively with the mycelium of Pleurotus pulmonarius and Pleurotus ostreatus in vitro and reducing the production surface from 30 to $50 \%$. Considering the above, an experiment was conducted to develop a suitable management practice against the competitor moulds of $P$. florida in use of various fungicides.

\section{Materials and Methods}

\section{Screening of Natural Incidence of} Competitor Moulds: Ten home scale mushroom farms of Thanjavur and its nearby areas were surveyed every month from March 2015 to February 2016 for the occurrence of contamination in mushroom beds of oyster mushroom (Pleurotus florida). The incidences of different competitor moulds were recorded. Infected mushroom bags were tagged and the contaminated micro floras were identified. Total numbers of infected beds were counted from each farm. In addition, five mushroom beds were raised in first week of every month and allowed for spawning and yield at Sri Amman Biocare mushroom unit, Thirukkanurpatti, Thanjavur District.

A month wise average data on mean temperature, relative humidity were recorded. Spawn of oyster mushroom (Pleurotus florida) was supplied from the Sri Amman Biocare to the progressive farmers for cultivation. Paddy straw was taken as substrate and chemical sterilization technique was followed in cultivation. Container system of cultivation (polypropylene bags) was followed in all experiments. Samples of various diseases and the competitor fungi were collected on a regular basis from the cropping room and subsequently, in vitro studies have been carried out in laboratory.

Preparation of Beds: Chopped paddy straw was soaked into a solution containing the require amount of sterilizing agent for 10-12 hours. The substrate was filled in polypropylene bags as layer by layer and each layer spawn was inoculated. A unit of $3 \mathrm{~kg}$ of dry straw was used for each treatment, which was equally distributed in 3 bags representing each as a replication. The moisture content of the straw at the time of spawning was kept around 70 - 75\%. The filled bags were incubated in a dark room at a temperature ranging between $24-30^{\circ} \mathrm{C}$, where $90 \%$ relative humidity was maintained till the spawn run was complete. When the straw is fully covered with milky white mycelium in the bag, it is regarded as complete spawn run, then the bags were hanged by nylon string at a distance of $60 \mathrm{~cm}$. Harvesting was done when the fruit body was mature.

\section{Isolation and Purification of Competitor} Moulds: Competitor moulds fungi were collected from the damaged beds in sterilized Petri plates with the help of a sterile forceps and thereafter transferred into PDA plates under in vitro conditions. Inoculated PDA plates were incubated at $27^{\circ} \mathrm{C} \pm 2^{\circ} \mathrm{C}$ for $72 \mathrm{~h}$. A single colony was isolated from the PDA plate and again transferred to PDA plates for obtaining the pure culture. All the pure cultures were kept in refrigerator at $4^{\circ} \mathrm{C}$ for preservation.

In vitro study: Three different treatments were used to control the competitor mould in in vitro condition, such as treatment 1 (T1) was $0.01 \mathrm{~g} / 100 \mathrm{ml}$ of chemical fungicides (carbendazim (50\% WP), mancozeb (75\% WP) and zineb (75\% WP)), treatment 2 (T2) was $0.005 \mathrm{~g}+0.1 \mathrm{ml} / 100 \mathrm{ml}$ (chemical 
fungicides with formalin) and treatment 3 (T3) $0.01 \mathrm{~g}+0.15 \quad \mathrm{ml} / 100 \mathrm{ml}$ (chemical fungicides with formalin) were used against competitor moulds T. viride, Trichoderma harzianum, Penicillium notatum, Aspergillus niger, Aspergillus flavus, Mucor sp., Rhizopus sp., and Sclerotium Rolfsii by using disc diffusion method on PDA medium (Kirby et al., 1966).

\section{Results and Discussion}

Role of Meteorological Factors: The survey of effect of fluctuations in temperature and relative humidity on the incidence of competitor moulds and yield of oyster mushroom was studied and the data obtained are presented in Table 1 . Survey revealed the occurrence of eight contaminants i.e. $T$. viride, T. harzianum, $P$. notatum, A. niger, A. flavus, Mucor sp., Rhizopus sp., and S. Rolfsii out of which T. harzianum, $T$. viride, A. niger and P. notatum were found to be the most dominant fungal contaminants. The incidence of the contaminants were minimum during the month of December and January $(3.6 \%)$ and it increased considerably with the fluctuating climatic conditions and reached its peak during the month of May and June $(26.5 \%)$. Thereafter, a decline trend in contamination \% was noticed in this region. Minimum range of contamination (3.6 to $6.8 \%$ ) was observed during the period from November to January and again August, when maximum biological efficiency $107 \%$ was obtained. A range of average maximum temperature $\left(27.4-34.6^{\circ} \mathrm{C}\right)$, minimum temperature $\left(13.4-22.7^{\circ} \mathrm{C}\right)$ was found most appropriate for the cultivation of oyster mushroom in this region (Table-1,2).

In vitro study: The extent of antifungal experiment carried out against different competitor moulds by use of three different treatments (Table 2). Significant differences were obtained among all the treatments. Treatment 3 (T3) $0.01 \mathrm{~g}+0.15 \mathrm{ml} / 100 \mathrm{ml}$ (chemical fungicides with formalin) proved its superiority among all the treatments and found to be most effective in inhibiting the mycelial growth of three contaminants (20.15, 19.20 and $17.40 \mathrm{~mm}$ ) i.e T. viride, Mucor sp. and $P$. notatum respectively and treatment 2 (T2) was found less effective against the mycelium growth of $S$. rolfsii, $T$. harzianum, A. niger and A. flavus. Treatment 1 (T1) was does not form zone of inhibition against competitor mould and Rhizopus sp. was does not inhibited by all treatments (Table-3, 4 and $5)$.

Table.1 List of competitor mould isolated in oyster mushroom cultivation

\begin{tabular}{|c|l|}
\hline S.No & Organisms isolated \\
\hline 1. & T. viride \\
\hline 2. & T. harzianum \\
\hline 3. & P. notatum \\
\hline 4. & A. niger \\
\hline 5. & A. flavus \\
\hline 6. & Mucor $\mathrm{sp}$. \\
\hline 7. & Rhizopus $\mathrm{sp}$ \\
\hline 8. & S. rolfsii \\
\hline
\end{tabular}


Table.2 Month wise mean temperature, mean total contamination $\%$ and yield biological efficiency of mushroom cultivation.

\begin{tabular}{|l|c|c|c|}
\hline \multicolumn{1}{|c|}{ Month } & $\begin{array}{c}\text { Mean } \\
\text { Temperature }^{\mathbf{o}} \mathbf{C}\end{array}$ & $\begin{array}{c}\text { Mean Total } \\
\text { Contamination } \\
\text { \% }\end{array}$ & $\begin{array}{c}\text { Yield } \\
\text { biological } \\
\text { efficiency \% }\end{array}$ \\
\hline January & 22.7 & 3.67 & 104.5 \\
\hline February & 25.2 & 4.10 & 103.0 \\
\hline March & 26.6 & 5.80 & 101.4 \\
\hline April & 28.7 & 12.15 & 100.5 \\
\hline May & 34.6 & 26.50 & 90.6 \\
\hline June & 29.3 & 20.30 & 96.5 \\
\hline July & 27.4 & 12.40 & 100.2 \\
\hline August & 23.5 & 6.80 & 104.0 \\
\hline September & 24.5 & 7.20 & 105.0 \\
\hline October & 13.4 & 6.15 & 107.0 \\
\hline November & 19.3 & 5.80 & 106.5 \\
\hline December & 20.5 & 3.60 & 106.0 \\
\hline
\end{tabular}

Table.3 Effect of chemical fungicide on the growth of competitor moulds (Treatment I)

\begin{tabular}{|c|l|c|c|c|}
\hline \multirow{2}{*}{ S.No. } & \multirow{2}{*}{ Organisms } & \multicolumn{3}{|c|}{ Zone of inhibition in $\mathrm{mm}$} \\
\cline { 3 - 5 } & Carbendazim & Mancozeb & Zineb \\
\hline 1 & A. niger & 11.57 & 10.33 & 6.35 \\
\hline 2 & Rhizopus sp. & Nil & Nil & Nil \\
\hline 3 & T. viride & 16.32 & Nil & 5.7 \\
\hline 4 & T. harzianum & Nil & Nil & Nil \\
\hline 5 & Mucor sp. & 17.80 & 8.9 & Nil \\
\hline 6 & S. rolfsii & 13.16 & 12.1 & 8.86 \\
\hline 7 & P. notatum & 12.10 & 10.60 & 11.5 \\
\hline 8 & A. flavus & 10.61 & 9.85 & 10.40 \\
\hline
\end{tabular}

Table.4 Effect of chemical fungicide on the growth of competitor moulds (Treatment II)

\begin{tabular}{|c|l|c|c|c|}
\hline \multirow{2}{*}{ S.No. } & \multirow{2}{*}{ Organisms } & \multicolumn{3}{|c|}{ Zone of inhibition in mm } \\
\cline { 3 - 5 } & A. niger & Carbendazim & Mancozeb & Zineb \\
\hline 1 & A. & 13.15 & 11.50 & 8.50 \\
\hline 2 & Rhizopus sp. & Nil & Nil & Nil \\
\hline 3 & T. viride & 19.75 & 10.40 & 9.65 \\
\hline 4 & T. harzianum & 14.25 & 12.25 & 11.55 \\
\hline 5 & Mucor sp. & 18.00 & 15.9 & 7.25 \\
\hline 6 & S. rolfsii & 14.70 & 12.1 & 8.86 \\
\hline 7 & P. notatum & 14.65 & 12.20 & 12.10 \\
\hline 8 & A. flavus & 11.10 & 10.50 & 10.20 \\
\hline
\end{tabular}


Table.5 Effect of chemical fungicide on the growth of competitor moulds (Treatment III)

\begin{tabular}{|c|l|c|c|c|}
\hline \multirow{2}{*}{ S.No. } & \multirow{2}{*}{ Organisms } & \multicolumn{3}{|c|}{ Zone of inhibition in mm } \\
\cline { 3 - 5 } & Carbendazim & Mancozeb & Zineb \\
\hline 1 & A. niger & 14.20 & 11.90 & 10.10 \\
\hline 2 & Rhizopus sp. & 6.40 & Nil & Nil \\
\hline 3 & T. viride & 20.15 & 12.50 & 10.55 \\
\hline 4 & T. harzianum & 16.15 & 11.75 & 12.50 \\
\hline 5 & Mucor sp. & 19.20 & 14.10 & 11.70 \\
\hline 6 & S. rolfsii & 16.80 & 14.20 & 10.00 \\
\hline 7 & P. notatum & 17.40 & 14.60 & 15.40 \\
\hline 8 & A. flavus & 13.20 & 12.50 & 12.00 \\
\hline
\end{tabular}

Fig.1 Effect of chemical fungicide on the growth of competitor moulds (Treatment I)

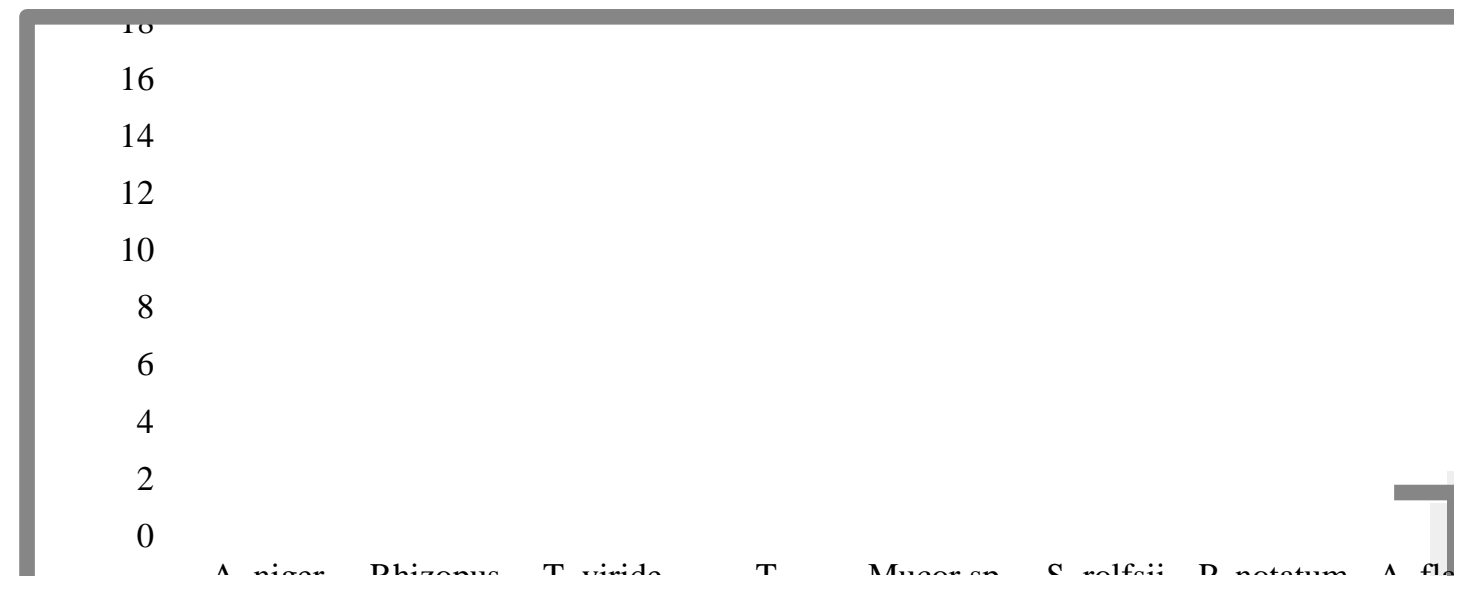

Fig.2 Effect of chemical fungicide on the growth of competitor moulds (Treatment II)

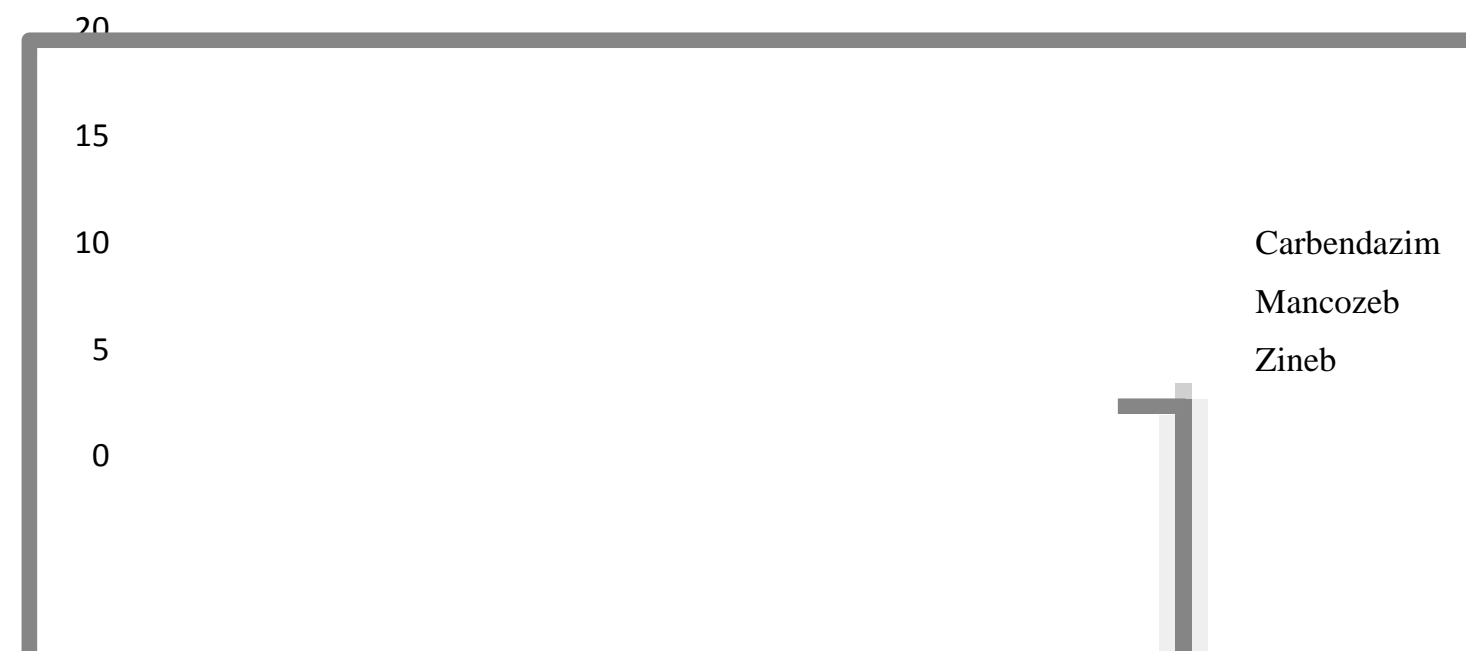


Fig.3 Effect of chemical fungicide on the growth of competitor moulds (Treatment III)

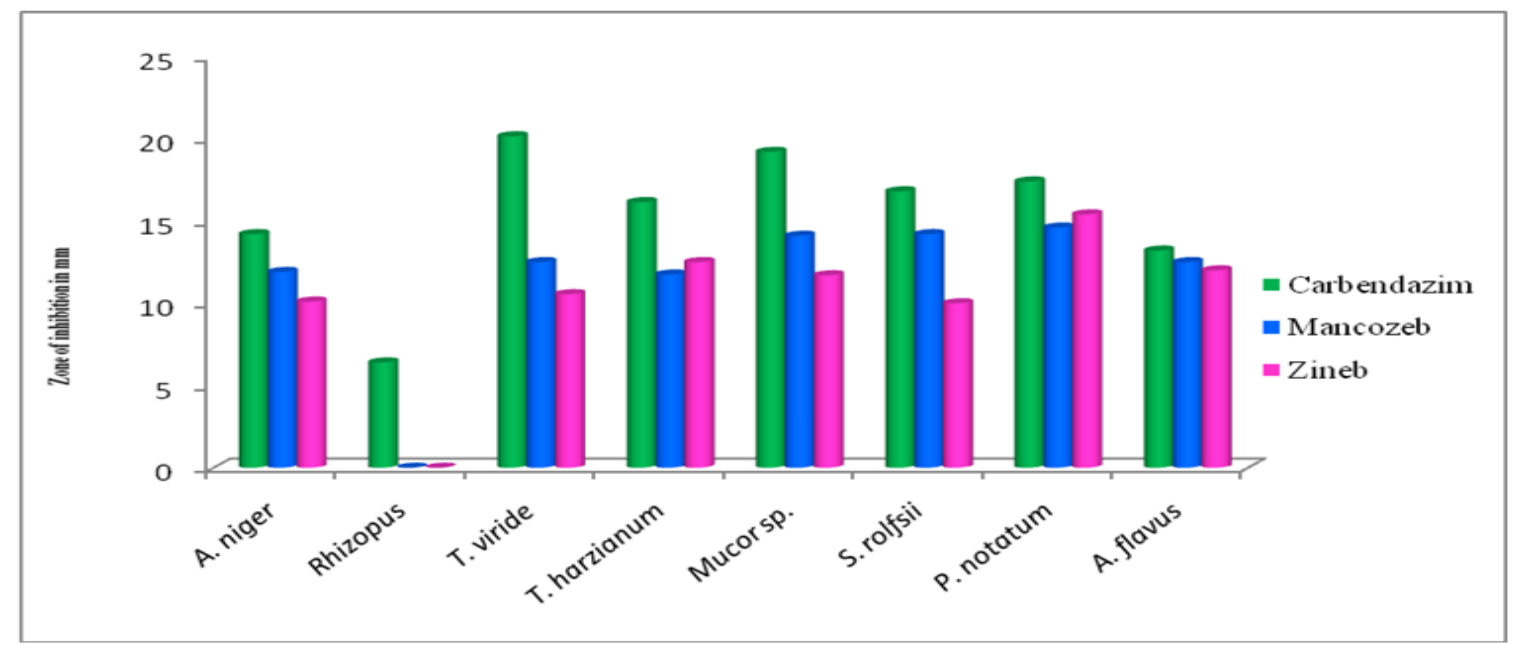

The optimal temperature for the spread of the mycelium or vegetative growth of Pleurotus sp. is around $25-28^{\circ} \mathrm{C}$ and for fruiting body formation the temperature requirement is nearly 2 to $4^{\circ} \mathrm{C}$ less than that. If there is too cold then the mycelial growth is to be arrested and at more than optimum temperature there is the risk of mould and bacterial contamination on the production beds which leads to destruction of the mushroom mycelia. In present investigation, heavy rain coupled with elevated minimum temperature $\left(>25^{\circ} \mathrm{C}\right)$ increased the contamination in beds was probably due to the decreasing of oxygen supply and increase in $\mathrm{CO}_{2}$ concentration in the mushroom house or growing bags which may reduce the growth rate of oyster mushroom mycelia. Different concentration of carbendazim (bavistin) and its combination with formaldehyde (formalin) were evaluated against the major contaminants of $P$. sajorcaju, $P$. flabellatus and $P$. citrinipileatus (Upadhyay et al., 1987; Vijay et al., 1987) and they reported complete inhibition of the mould fungi under in vitro and/ or in vivo. Complete inhibition of most of the competitor moulds of oyster mushroom was obtained with the application of $50 \mathrm{ppm}$ benomyl + $100 \mathrm{ppm}$ thiram. In the present study the inhibition patterns of (carbendazim $(50 \%$ WP), mancozeb (75\% WP) and zineb (75\%
WP)) against the competitor moulds in vitro further support the findings of Jain and Vyas (Jain et al., 2002).

In conclusion, survey revealed the occurrence of eight competitor moulds were identified out of which T. harzianum, T. viride, A. niger and $P$. notatum were found to be the most dominant fungal contaminants. The incidence of the contaminants were minimum during the month of December and January $(2.60 \%)$ and it increased considerably with the fluctuating climatic conditions and reached its peak during the month of May and June (21.5\%).

The extent of antifungal experiment treatment 3 (T3) $0.01 \mathrm{~g}+0.15 \mathrm{ml} / 100 \mathrm{ml}$ (chemical fungicides with formalin) proved its superiority among all the treatments and found to be most effective in inhibiting the mycelial growth of three contaminants (20.15, 19.20 and $17.40 \mathrm{~mm}$ ) i.e T. viride, Mucor sp. and $P$. notatum compared with other treatments and Rhizopus sp. was does not inhibited by all treatments.

\section{References}

Balaza, S. and Szabo, I. 1979. Temperature requirement studies of some new mushroom species in culture. Mush. Sci., 
10(2): 421-427.

Banik, S. and Nandi, R. 2004. Effect of supplementation of rice straw with biogas residual slurry manure on the yield, protein and mineral contents of oyster mushroom. Ind. Crops Prod., 20: 311-319.

Castle, A., D. Speranzini, N. Rghei, Glen Alm, D. Rinker, and J. Bissett. 1998. Morphological and molecular identification of Trichoderma isolates on North American mushroom farms. Appl. Environ. Microbiol., 64(1): 133-137.

Doshi, A. and Singh, R.D. 1985. Control of weed fungi and their effect on yield of oyster mushroom Pleurotus sajor-caju. Indian J.Mycol. Plant Pathol., 15: 269273.

Fan, L., A., Pandey and Carlos, R. Soccol 2000a. Solid state culturing-an efficient technique to utilize toxic agro-industrial residue. J. Basic Microbiol., 40: 177-187.

Fan, L., A., Pandey and Carlos, R. Soccol. 2000b. Comparison of coffee industry residues for production of Pleurotus ostreatus solid state fermentation. Acta Biotechnol., 20: 41-52

Gregori, A., M. vagelj and J. Pohleven. 2007. Cultivation techniques and medicinal properties of Pleurotus sp. Food Technol. Biotechnol., 45(3): 238-249.

Hermosa, M.R., I. Grondona, and E. Monte. 1999. Isolation of Trichoderma harzianum Th2 from commercial mushroom compost in Spain. Plant Dis., 83: 591.

Jain, A.K. and Vyas, D. 2002. Yield response of Pleurotus florida on wheat straw in combination with other substrates. Mush. Res., 11(1): 19-20.

Kirby Bauer, A.W., Kirby,W.M.M., Serris, J.C and Turek, M. 1966. Antibiotic susceptibility testing by a standardized single disc method. Am. J. clinic. Pathol. 45 : 493-496.

Liu, G.Q., Wang, X.L. 2009. Selection of a culture medium for reducing costs and intracellular polysaccharide production by Agaricus blazei AB2003. Food Technol Biotechnol., 47:210-214.

Mamoun, M.L., G. Mata and J.M. Savoie. 2000. Interactions between the pathogen Trichoderma harzianum Th2 and Agaricus bisporus in mushroom compost. Mycologia, 92: 233-240.

Murthy, P.S. and Manonmani, H.K. 2008. Bioconversion of coffee industry wastes with white rot fungus Pleurotus florida. Res. J. Environ. Sci., 2(2): 145-150.

Naraian, N, Sahu RK, Kumar, Garg, SK, Singh C S and Kanaujia, RS. 2009. Influence of different nitrogen rich supplements during cultivation of Pleurotus florida on corn cob substrate. Environmentalist, 29(1):1-7.

Sharma, A.D. and Jandaik, C.L. 1983. Some preliminary observations on the occurrence of Siberian rot of cultivated mushrooms in India and its control. Tai. Mush., 6(1,2): 38-42.

Shin, G.C. 1987. Harmful fungi associated with rice straw media for growing of oyster mushroom, Pleurotus ostreatus. Kor. J. Mycol., 15: 92-98.

Upadhyay, R.C., Vijay, B. and Sohi, H.S. 1987. Pleurotus species (oyster or dhingri mushroom) Annual report of National Center of Mushroom Research and Training. pp 20-25.

Vijay, B. and Sohi, H.S. 1987. Effect of different sterilants and farm wastes on yield of Pleurotus citrinopileatus. Mush. J. Tropics, 7: 67-75.

\section{How to cite this article:}

Senthil Kumar, R., and Sarathi, V. 2017. Screening of Competitor Mould in Oyster Mushroom (Pleurotus florida) Cultivation and their Management. Int.J.Curr.Microbiol.App.Sci. 6(1): 264270. doi: http://dx.doi.org/10.20546/ijcmas.2017.601.032 